\title{
PENGGUNAAN MEDIA PAJS UNTUK MENGEMBANGKAN KECERDASAN MATEMATIS DAN INTERPERSONAL PESERTA DIDIK DALAM PEMBELAJARAN MATEMATIKA MATERI SKALA
}

\author{
Hardani \\ UPTD SDN Tambegan Arosbaya Bangkalan
}

\begin{abstract}
Abstrak. Penelitian ini bertujuan untuk mengetahui peningkatan kecerdasan matematika dan interpersonal siswa dalam pembelajaran matematika materi skala menggunakan media Papan Ayak Jarak Sebenarnya. Penelitian ini merupakan penelitian pengembangan yang digunakan untuk mengembangkan media pembelajaran matematika di kelas enam Sekolah Dasar UPTD Tambegan. Hasil belajar yang dilakukan sebelumnya tidak menunjukkan perkembangan kecerdasan matematika dan interpersonal siswa yang baik. Tahapan penggunaan media ini meliputi tahap pahami, lakukan, temukan, hitung, dan komunikasikan. Melalui penggunakan media PJAS dengan tahapan tersebut peserta didik melakukan kegiatan pengukuran, analisis, menyusun permasalahan dan solusi penyelesaian secara mandiri. Selain itu, permainan dalam penggunaan media PAJS dapat mengembangkan kemampuan untuk bekerja bersama, kemampuan untuk percaya diri, kemampuan untuk memotivasi orang lain, saling menghormati. Sehingga penggunaan media PAJS dapat meningkatkan kecerdasan matematika dan interpersonal siswa.
\end{abstract}

Kata kunci: media PAJS, kecerdasan matematis dan interpersonal, materi skala

\section{THE USE OF PAJS MEDIA TO IMPROVE STUDENTS' MATHEMATICAL AND INTERPERSONAL INTELLIGENCE IN TEACHING AND LEARNING PROCESS FOR THE TOPIC OF 'SCALE'}

\begin{abstract}
This study aims to determine the improvement of the development of mathematical and interpersonal intelligence of students in learning mathematics of scale material using the actual Sifter Board media. This research is a development research used to develop mathematics learning media in the sixth grade of the UPTD Tambegan Elementary School. Learning outcomes that were carried out previously showed no development of students' mathematical and interpersonal intelligence. After the learning with PAS media was carried out, students were not only able to work on material scale questions, but with the material acquisition activities they were able to make problems and do it correctly. In addition, the stages of using PAS media can develop the ability to work together, the ability to be confident, the ability to motivate others, mutual respect. Based on the results obtained it can be concluded that the use of PAJS media can improve students' mathematical and interpersonal intelligence.
\end{abstract}

Keywords: scale, mathematical and interpersonal intelligence material, PAIS 


\section{Pendahuluan}

Pembelajaran merupakan suatu kegiatan yang dilakukan antara peserta didik dengan guru melalui suatu proses dalam lingkungan belajar. Pembelajaran juga dapat dikatakan sebagai suatu proses menyampaikan ilmu antara guru dan peserta didik. Guru dalam kegiatan pembelajaran berperan sebagai penyampai informasi dan peran peserta didik sebagai penerima informasi. Kegiatan penyampaian informasi tersebut dilakukan melalui pembelajaran yang efektif. Sudjana (2013:4) menyatakan bahwa pembelajaran akan efektif apabila berpedoman pada hasil juga pada prosesnya. Dari pendapat ini dapat dinyatakan bahwa semakin baik proses pembelajaran yang dilakukan guru, semakin baik pula hasil yang akan diperoleh. Penilaian yang digunakan untuk pembelajaran tersebut menggunakan indikator proses dan hasil belajar.

Proses pembelajaran hendaknya dilaksanakan dengan kontekstual melalui kegiatan penemuan. Peserta didik dikenalkan dengan permasalahan yang sesuai dengan keadaan sekarang yang terjadi. Pembelajaran ditekankan pada proses pemerolehan materi berdasarkan kegiatan yang dilakukan peserta didik melalui bimbingan guru. Materi matematika tidak hanya pada pengerjaan soal-soal latihan saja. Untuk itu, diperlukan media yang tepat untuk memfasilitasi peserta didik dalam proses pembelajaran.

Sebagai salah satu komponen pembelajaran, media mempunyai peran yang sangat penting. Media merupakan alat bantu yang digunakan guru menyampaikan pesan atau materi ajar kepada peserta didik untuk mencapai tujuan pembelajaran yang telah ditetapkan. Dalam menentukan media ada dua hal yang harus diperhatikan yaitu modalitas peserta didik dalam belajar dan prinsip pemilihan media pembelajaran. Modalitas belajar yang dimiliki peserta didik dalam belajar yaitu visual, auditorial, dan kinestetik (Chatib, 2015:122). Prinsip pemilihan media dalam pembelajaran yaitu kesesuaian tujuan, kesesuaian karakter peserta didik, dapat menjadi sumber belajar, efisien dan efektif, aman bagi peserta didik, dapat meningkatkan keaktifan peserta didik, membuat suasana pembelajaran yang menyenangkan (Akbar, 2013:118). Dengan memperhatikan dua hal tersebut media yang digunakan akan membuat pembelajaran menjadi efektif, namun demikian, masih sering diabaikan.

Mempelajari matematika akan melatih peserta didik untuk berfikir sistematis, logis, kritis, rasional dan bersikap efektif. Oleh karena itu dalam pembelajaran matematika ini guru harus benar-benar mengetahui kemampuan peserta didik, sebagai upaya dalam menentukan media yang digunakan. Ketepatan pemilihan media berdampak pada keberhasilan pembelajaran yang dilaksanakan. Pembelajaran yang berhasil tidak hanya mampu mengembangkan salah satu kecerdasan yang dimiliki oleh peserta didik, melainkan diharapkan beberapa kecerdasan mampu dikembangkan. Dalam teori psikologi Gardner seperti yang dikemukakan Chatib (2016:138) ada delapan kecerdasan yang dapat dilatih terus menerus dan diberikan stimulus agar mempunyai kondisi akhir yang terbaik yaitu kecerdasan verbal (linguistik), matematislogis, visual spasial, musik, kinestetis, interpersonal, intrapersonal dan naturalis.

Matematika masih menjadi salah satu pelajaran yang "membosankan" bagi sebagian besar peserta didik di sekolah dasar. Hal ini disebabkan selama ini pembelajaran yang dilakukan guru dilakukan dengan hafalan rumus dan disertai dengan pengerjaan soal yang banyak. Oleh karena ini dalam pembelajaran matematika perlu dikembangkan media yang dikemas 
dengan tahapan-tahapan menyenangkan sesuai dengan indikator yang diharapkan.Melalui tahapan inidiharapkan seluruh kecerdasan yang dimiliki peserta didik dapat berkembang dengan baik. Hal ini disebabkan setiap peserta didik mempunyai karakteristik dan kecenderungan kecerdasan yang berbeda-beda. Sehingga diperlukan media yang sesuai dengan gaya belajar peserta didik serta mampu mengembangkan kecerdasan mereka.

Di dalam silabus kelas VI semester II terdapat materi tentang skala. Materi ini mengajarkan peserta didik kelas VI agar mampu mengetahui tentang jarak sebenarnya, jarak pada peta dan skala. Setalah penanam konsep tentang skala, jarak peta dan jarak sebenarnya, selanjutnya pembelajaran diajarkan dengan cara memberikan materi berupa rumus dan soal cerita untuk dikerjakan peserta didik. Tidak ada media yang digunakan guru dalam pembelajaran. Letak lokasi digambarkan dengan kota A, kota B yang sangat abstrak bagi peserta didik. Ini seringkali membuat soal yang diberikan belum sesuai dengan keadaan yang sebenarnya. Soal hanya sebatas imajinasi pembuat soal saja, dan tidak menggambarkan kondisi nyata. Kegiatan seperti ini tentunya hanya melatih kemampuan peserta didik untuk dapat menjawab pertanyaan berdasarkan rumus yang ada. Kondisi ini menyebabkan hasil belajar yang diperoleh peserta didik tidak dapat diaplikasikan dalam kehidupan sehari-hari mereka. Sehingga kecerdasan matematisnya belum tercapai.

Pembelajaran matematika sebenarnya tidak hanya pada kemampuan matematis saja.Kegiatan pembelajaran pada materi skala yang dilakukan dapat juga bisa diintegrasikan dengan berbagai perkembangan sosial peserta didik. Perkembangan yang dimaksud yaitu kecerdasan interpersonal.

Kecerdasan interpersonal merupakan kemampuan mengamati, memahami maksud dan perasaan orang lain serta menjalin komunikasi efektif dengan orang lain. (English, 2017:158). Kecerdasan ini diperlukan bagi peserta didik dalam mengadapi dunia nyata mereka. Kemampuan berinteraksi baik dengan orang lain. Dengan kemampuan dan keterampilan interpersonal ini peserta didik akan dilatih untuk dapat bekerja dalam berbagai situasi yang memungkinkannya menjadi sosial, merencanakan secara bersama, dan bekerja dengan orang lain. Keterampilan seperti itulah yang jarang dikembangkan oleh guru. Pembelajaran yang dilaksanakan tidak mengembangkan kemampuan yang dimiliki peserta didik dengan kecerdasan yang berbeda-beda. Pembelajaran tentang materi skala yang hanya memberikan soal latihan seringkali membuat peserta didik menjadi bosan. Padahal tidak semua peserta didik mempunyai kemampuan dan kecenderungan kecerdasan yang sama pada bidang matematika. Bagi peserta didik yang kurang dalam kecerdasan matematis, terlihat kurang antusias mengikuti pembelajaran.

Salah satu media yang dapat dikembangkan dalam pembelajaran tersebut yaitumedia PAJS (Papan Ayak Jarak Sebenarnya). Media ini digunakan dalam mata pelajaran matematika pada materi skala. Medianya berupa papan dengan alas triplek yang di atasnya diberikan sterofoam bermagnet dan peta. Penggunaannya dilakukan secara berkelompok yang terdiri dari lima orang peserta didik. empat orang sebagai pemain pembantu dengan cara melakukan gerakan mengayun ke depan dan belakang sambil menyanyikan lagu daerah. Satu orang sebagai pemain inti yang melemparkan dua buah gotri sebagai penanda dua lokasi. Dengan adanya dua lokasi yang diberi tanda dengan gotri tersebut, dapat dibuat pertanyaan untuk 
mencari jarak sebenarnya dari lokasi tersebut. Berikut media yang digunakan dalam peserta didik.

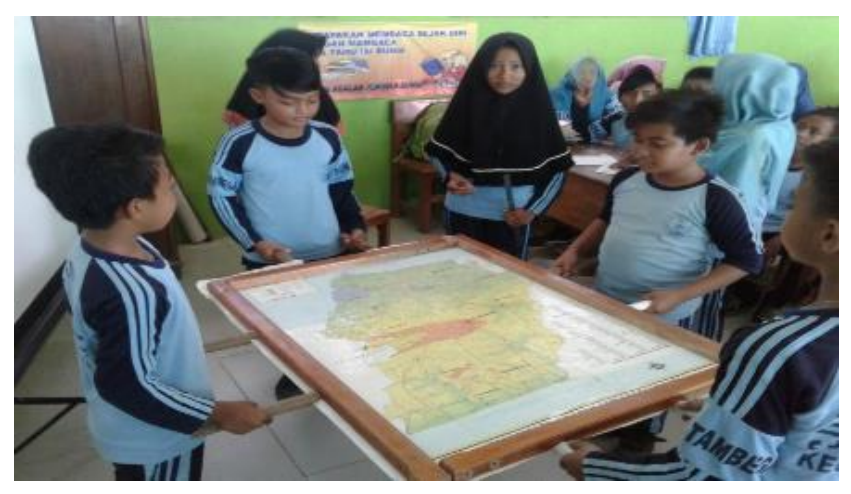

Gambar 1. Media PAJS dalam Penggunaannya

Pengembangan produk inovasi berupa media pembelajaran ini karena lebih menekankan pada prosesnya. Melalui permainan yang menyenangkan dapat memberikan stimulus kepada peserta didik untuk mempelajari materi pelajaran. Hal ini disebabkan permainan merupakan hal yang paling disukai karena sesuai dengan perkembangan anak usia SD yang masih senang bermain. Bahkan sebagian besar anak, permainan bisa menjadi sarana mereka untuk mengutarakan perasaan yang dialami sehari-hari. Seperti pendapat Murniati (2012:35), yang menyatakan bahwa: "setiap permainan yang dilakukan anak memiliki fungsi yang berhubungan langsung dengan badan atau tubuh mereka dan meningkatkan konsentrasi dan antusiasme anak dalam suatu kegiatan." Selain itu pada prosesnya dapat mengembangkan berbagai kemampuan berfikir kritis, problem solving serta kecerdasan peserta didik. Media ini tidak hanya memiliki fungsi untuk menarik perhatian peserta didik dalam pembelajaran. Penggunaan media yang disertai dengan kegiatan menyanyikan lagu, diharapkan peserta didik akan menjadi tertarik dan senang. Kerjasama antar peserta didik dalam kelompok dibutuhkan dalam memainkan media ini. Proses pembelajaran dengan media ini menuntut keterampilan mengukur, menganalisis dan berfikir kritis dalam menyelesaikan permasalahan. Selain itu penggunaan media ini dapat memberikan penguatan materi yang telah diajarkan oleh guru.

Tujuan penggunaan media papan ayak jarak sebenarnya pembelajaran ini untuk mengembangkankecerdasan matematis dan interpersonal peserta didik dalam pembelajaran matematika materi skala.

Materi skala diajarkan guru dengan memberikan rumus dan soal cerita. Tentunya kegiatan pembelajaran ini hanya cocok bagi peserta didik dengan kecerdasan matematis yang baik. Bagi peserta didik yang lain akan sangat membosankan. Dengan tidak ada media yang relevan serta beberapa soal yang tidak sesuai dengan keadaan yang sebenarnya membuat pembelajaran tidak bermakna.

Berdasarkan permasalahan tersebut, penulis mengembangkan media pembelajaran matematika pada materi skala dengan media papan ayak sebenarnya yang dilakukan melalui permainan dan menyanyi. Kegiatan ini dikombinasikan dengan tahapan-tahapan yang telah didesain sebelumnya yaitu Pahami, Lakukan, Temukan, Hitung, Komunikasikan. Melalui 
tahapan ini diharapkan media yang digunakan tidak hanya berperan sebagai pemberi stimulus, namun juga memberikan penguatan dan peningkatan keterampilan peserta didik dalam memahami materi melalui proses yang kontekstual.

Media Papan Ayak sebenarnya ini dibuat dari bahan dasar triplek, diatasnya diberi sterefoam yang telah diberikan magnet-magnet. Magnet ini diletakkan sesuai dengan titik-titik lokasi wilayah yang ada pada peta di atasnya. Penggunaannya dilakukan secara berkelompok yang terdiri dari lima orang. Empat orang sebagai pemain membantu yang memainkan medianya dan satu orang sebagai pemain utama. Pemain pembantu tugasnya membantu proses penemuan materi melalui kegiatan mendorong ke depan dan belakang secara serasi dan selaras dengan lagu yang dinyanyikan bersama. Pemain utama bertugas melemparkan gotri, melakukan pengamatan letak gotri, pengukuran jarak yang dibentuk gotri, melakukan perhitungan mencari jarak sebenarnya dan mengkomunikasikan dengan bahasa tulis atau lisan di akhir kegiatan.

Tahapan kegiatan:

1) Pada tahap Pahami.

Pada tahap ini guru memberikan penjelasan tentang materi skala, melalui kegiatan tanya jawab, diskusi klasikal. Dalam kegiatan ini peserta didik diharapkan memahami materi tentang skala. Selanjutnya guru menunjukkan media PJAS kepada peserta didik dan cara menggunakan media tersebut.

2) Tahap Lakukan.

Pada tahap ini peserta didik bersama kelompoknya menggunakan media. Dalam satu kelompok terdiri dari lima orang. Empat orang sebagai pemain pembantu, satu orang sebagai pemain utama. Pemilihan pemain pembantu dan inti dilakukan secara bergiliran dan dilakukan dengan suit atau hompimpa. Empat orang pemain pembantu tugasnya melakukan gerakan mendorong ke depan dan ke belakang secara serasi dan selaras dengan lagu yang dinyanyikan. Lagu ini merupakan lagu daerah Madura Gai' Bintang. Bersamaan dengan berakhirnya lagu yang dinyanyikan, pemain utama melemparkan dua buah gotri ke bidang PJAS.

3) Temukan

Pada tahap temukan peserta didik melakukan pengamatan terhadap berhentinya gotri pada suatu titik. Selanjutnya peserta didik menemukan sendiri materi melalui kegiatan mengamati, melakukan eksperiman dengan mengukur berkaitan dengan permasalahan menghitung jarak sebenarnya dari dua lokasi yang dibentuk oleh gotri tersebut.

4) Tahap Hitung

Pada tahap ini peserta didik menghitung jarak sebenarnya dari lokasi yang ditunjuk gotri berdasar pengetahuan yang diperoleh sebelumnya. 
Pada tahap ini, peserta didik mengkomunikasikan hasil kegiatan yang telah dilakukan baik dengan tulis maupun lisan dalam bentuk soal beserta penyelesaiannya.

\section{Metodologi Penelitian}

Metodologi yang digunakan dalam mengembangkan produk inovasi ini menggunakan penelitian pengembangan $\mathrm{R} \& \mathrm{D}$ dengan model Analysis Design Development Implementation Evaluation (ADDIE) yang dikembangkan oleh Reiser dan Mollenda. Tahapan penelitian pengembangan ini meliputi Analysis (analisis), Design (rancangan), Development (pengembangan), Implementation (Implementasi, dan Evaluation (Evaluasi). Pada tahap analisis dilakukan dengan analisis kebutuhan, analisis kurikulum dan analisis karakter. Pada tahap analisis kebutuhan dilakukan untuk menganalisis kebutuhan media konrit dalam materi skala ini. Setelah penanaman konsep tentang materi skala kegiatan hanya sebatas meningkatkan keterampilan melalui soal.Soal tersebut seringkali tidak sesuai dengan keadaan nyata. Menganalisis hasil pembelajaran matematika pada materi skala, yang meliputi analisis proses dan hasil. Tahap analisis kurikulum dilakukan dengan menganalisis materi skala pada kelas VI. Dalam tahap analisis karakter, peserta didik di kelas ini sangat menyenangi kegiatan yang sifatnya bermain. Sehingga diperlukan suatu media dalam pembelajaran matematika materi skala ini. Pada tahap Design, kegiatan yang dilakukan mengumpulkan alat dan bahan dalam serta mempersiapkan instrument validasi materi dan media. Pada tahapan Development, kegiatannya merancang produk inovasi media pembelajaran Papan Ayak Sebenarnya.Hasil rancangan ini, kemudian dikembangkan menjadi suatu media yang siap digunakan. Pada tahap ini juga dilakukan validasi ahli materi dan media dengan melibatkan kepala sekolah dan pengawas. Hasil produk inovasi ini selanjutnya di implementasikan pada peserta didik kelas IV UPTD SD Negeri Tambegan Bangkalan. Pada tahap implementasi diberikan angket kepada peserta didik untuk media yang digunakan. Angket ini digunakan untuk mengetahui respon peserta didik terhadap penggunaan media dalam pembelajaran.Dari hasil implementasi ini kemudian dievaluasi berdasar pada instrument validasi materi, media dan instrument angket untuk diadakan perbaikan dan penyempurnaan.

Instrumen untuk mengukur perkembangan kecerdasan matematis peserta didik diperoleh melalui hasil tes dari pemecahan permasalahan materi skala dengan menggunakan media PAJS. Permasalahan yang dimaksud adalah ketepatan mengukur, menyusun soal, dan menyelesaikannya. Hasil tes ini dibandingkan dari kegiatan sebelum digunakan media dan setelahnya. Untuk mengukur perkembangan kecerdasan interpersonal digunakan instrument observasi dengan indikatorkecerdasan interpersonal yang dikemukakan English (2017:158) yang terdiri dari kerjasama, memotivasi orang lain, percaya diri, saling menghormati.

\section{Hasil dan Pembahasan}

Hasil yang dicapai dari pengembangan media pembelajaran ini diperoleh dari hasil observasi dan tes yang dilakukan pada saat kegiatan pembelajaran. Hasilnya dibandingkan dengan keadaan sebelum pembelajaran dengan menggunakan media papan ayak sebenarnya. Indikator observasi mengacu pada pengembangan keterampilan interpersonal yang meliputi 
kemampuan bekerjasama, percaya diri, kemampuan memotivasi orang lain, sikap saling menghormati. Masing-masing indikator diberikan skor dengan skala likert 1-5, sangat baik skor 5, baik skor 4, cukup skor 3, kurang skor 2 dan sangat kurang 1. Sedangkan hasil belajar diperoleh melali tes yang diberikan secara klasikal. Tes tersebut dibuat dengan berdasar penggunaan media pembelajaran yang digunakan.

Hasil yang diperoleh sebagai berikut:

Tabel 1. Hasil Tes

\begin{tabular}{|c|c|c|}
\hline Jenis tes & Nilai rata-rata & Ketuntasan \\
\hline Pre test & 65,6 & $56 \%$ \\
\hline Post tes & 88,4 & $92 \%$ \\
\hline
\end{tabular}

Tingkat kecerdasan matematis sebelum dilaksanakan pembelajaran dengan media PAJS sangat kurang. Hal ini terlihat dari kemampuan penalaran peserta didik dalam menyelesaikan soal berkaitan dengan skala. Hal ini dimungkinkan karena selama ini pada materi skala, peserta didik hanya disuguhkan pada soal-soal untuk dikerjakan, kemampuan menganalisa, mengamati kurang dikembangkan dengan optimal. Dari hasil pre test diperoleh nilai rata-rata sebesar 65,6 dengan prosentase peserta didik yang tuntas sebesar 56\%. Selanjutnya guru melaksanakan pembelajaran dengan menggunakan media PAJS yang didesain melalui permainan dan tahapan Pahami, Lakukan, Temukan, Hitung, Komunikasikan. Hasilnya diperoleh nilai rata-rata sebesar 88,4 dengan prosentase ketuntasan 92\%. Hasil ini menunjukkan media PAJS sangat efektif digunakan untuk mengembangkan kecerdasan matematis peserta didik. Proses penemuan materi melalui kegiatan mengamati, melakukan, menganalisis, menghitung dan mengkomunikasi memberikan kesempatan pada peserta didik untuk mengeksplorasi segala kemampuan yang dimilikinya.

Dalam kegiatan tersebut peserta didik tidak hanya dilatih untuk mengerjakan soal dengan benar, tetapi dapat menyelesaikan permasalahan untuk dipecahkan sendiri dengan pengetahuan yang diperoleh sebelumnya. Selama ini seringkali soal cerita yang ada tidak mencerminkan kondisi nyata, namun hanya untuk melatih keterampilan menyelesaikan soal menggunakan rumus yang ada. Dengan adanya media PAJS peserta didik benar-benar dihadapkan dengan permasalahan nyata. Ketelitian mengukur, ketepatan menganalisis data dengan proses ilmiah benar-benar dilatih dan dikembangkan. Penggunaan media PAJS melalui permainan ini sesuai dengan pendapat English (2017:74) bahwa seorang guru dapat membangkitkan kecerdasan logis/matematis di ruang kelas dengan cara memberikan aneka pelajaran melalui permainan, eksperiman, analogi.

Tabel 2. Hasil Observasi

\begin{tabular}{|c|c|}
\hline Indikator & Prosentase \\
\hline Kerjasama & $90,4 \%$ \\
\hline Percaya diri & $92,8 \%$ \\
\hline Memotivasi orang lain & $90,4 \%$ \\
\hline Saling menghormati & $94,4 \%$ \\
\hline Rata-rata & $90,42 \%$ \\
\hline
\end{tabular}


Berdasar pada hasil observasi yang dilakukan menunjukkan kecerdasan interpersonal yang diharapkan telah berkembang dengan baik. Hal ini terlihat dari rata-rata seluruh indikator menunjukkan prosentase sebesar 90,42\%. Sebelum pembelajaran dengan menggunakan media PAJS menunjukkan kecerdasan interpersonal peserta didik dalam kelompok kurang baik. Peserta didik masih terlihat keegoisannya, kurang percaya diri, kurang peduli serta kurang menghormati sesama teman. Pembelajaran dengan media PAJS yang dirancang melalui permainan kelompok yang dapat mengembangkan kecerdasan interpersonal peserta didik. Hal ini disebabkan dalam melaksanakan permainan diharapkan memiliki kemampuan memahami dan berinteraksi dengan temannya dengan baik. Melakukan gerakan mendorong ke depan dan kebelakang dengan empat orang pemain menuntut kerjasama yang baik. Peserta didik harus bisa saling menghormati dan memotivasi satu dengan yang lain untuk tujuan bersama, bukan saling menyalahkan. Pada proses pengukuran peserta didik juga dituntut untuk memiliki kepercayaan diri mengukur dengan teliti, melakukan analisis data dan menyusun permasalahan serta memberikan solusi pemecahan secara mandiri. Penggunaan media PAJS melalui permainan ini juga sesuai dengan yang disampaikan oleh English (2017:158) bahwa di ruang kelas aneka aktivitas kelompok, permainan kerjasama dan rencana tim kreatif dapat meningkatkan kecerdasan interpersonal.

Dari keberhasilan penggunaan media PAJS dengan permainan telah berhasil meningkatkan kecerdasan matematis dan interpersonal peserta didik. Kegiatan permainan memberikan stimulus di awal pembelajaran, sehingga peserta didik senang untuk mempelajari materi. Dengan ketertarikan peserta didik terhadap pembelajaran, membuat mereka lebih fokus dan berkonsentrasi seperti pendapat Murniati (2012:35), yaitu "setiap permainan yang dilakukan anak memiliki fungsi yang berhubungan langsung dengan badan atau tubuh mereka dan meningkatkan konsentrasi dan antusiasme anak dalam suatu kegiatan". Desain pembelajaran melalui tahapan-tahapan yang dilakukan dapat mencapai tujuan yang ditetapkan, yaitu mengembangkan kecerdasan yang dimiliki peserta didik. Hal ini seperti yang dinyatakan oleh Siddiq, (2008:1), mengatakan bahwa: "pembelajaran yang seharusnya dilakukan guru adalah pembelajaraan yang dapat membuat peserta didik atau peserta didik aktif, inovatif, kreatif, efektif dan menyenangkan sehingga akan membantu peserta didik dalam mengembangkan kemampuan berfikir peserta didik dengan tingkatan yang tinggi, berpikir lebih kritis dan kreatif.".

Penggunaan media PAJS melalui permainan tidak hanya melatih kemampuan kognitif saja, namun afektif dan psikomotorik juga dapat dikembangkan. Kemampuan kognitif (matematis) dapat dikembangkan pada saat peserta didik melakukan pengukuran dengan teliti, melakukan analisis temuan, menyusun dan menyelesaikan permasalahan. Sehingga dalam mempelajari materi skala, peserta didik tidak hanya mampu mengerjakan soal dengan benar, namun mereka dapat menyelesaikan sesuai dengan keadaan yang sebenarnya. Kemampuan afektif (interpersonal) dapat dikembangkan melalui kegiatan permainan dalam kelompok. Kemampuan bekerjasama, percaya diri, kemampuan memotivasi orang lain, sikap saling menghormati, merupakan kemampuan yang sangat dibutuhkan untuk berinteraksi baik dengan orang lain dan berguna bagi kehidupan nyata peserta didik. Kemampuan psikomotorik peserta didik dapat dikembangkan melalui kegiatan permainan yaitu dengan mendorong ke depan dan ke belakang dengan serasi dan selaras sambil menyanyi. Kegiatan ini tentunya menyenangkan peserta didik. Menyanyikan lagu sambil mendorong ke depan 
dan ke belakang dengan empat orang bukan hal yang mudah. Butuh keselarasan dan keserasian tangan antar masing-masing peserta didik.

Keberhasilan penggunaan media PAJS melalui permainan yang dapat meningkatkan kecerdasan matematis dan interpersonal memberikan manfaat bagi peserta didik untuk kehidupa nyata mereka. Hal ini seperti yang dikemukakan oleh Chatib (2015:65) kecerdasan seseorang selalu berkembang dinamis dan ini dapat dilatih dan dikembangkan melalui kebiasaan membuat produk (kreativitas) dan kebiasaan menyelesaikan masalah secara mandiri (Problem solving).

\section{Kesimpulan dan Saran}

Penggunaan Media Papan Ayak Jarak Sebenarnya yang dilakukan melalui tahap Pahami, Lakukan, Temukan, Hitung dan Komunikasikan dapat meningkatkan kecerdasan matematis dan interpersonal peserta didik. Pada tahap pahami media digunakan untuk memberikan pemahaman dalam mencari jarak sebenarnya dua titik lokasi yang berbeda dengan lebih nyata. Pada tahap Lakukan, media ini digunakan untuk mengembangkan kecerdasan interpersonal melalui permainan. Pada tahap temukan, media ini digunakan untuk menemukan sendiri materi melalui kegiatan mengamati, melakukan eksperiman dengan mengukur berkaitan dengan permasalahan menghitung jarak sebenarnya dari dua tempat. Pada tahap Hitung peserta didik dapat melakukan kegiatan menghitung jarak sebenarnya dari pemahaman konsep materi yang telah dikuasainya. Pada tahap Komunikasikan, peserta didik mengkomunikasikan hasil kegiatan yang telah dilakukan baik dengan tulis maupun lisan dalam bentuk soal beserta penyelesaiannya. Peningkatan kecerdasan matematis dan interpersonal peserta didik terbukti dari hasil tes dan observasi yang meningkat dibandingkan sebelum digunakan media PJAS ini.

\section{DAFTAR PUSTAKA}

Akbar, S. (2013). Instrumen perangkat pembelajaran. Bandung: Remaja Rosdakarya

Chatib, M. (2015). Sekolahnya manusia. Bandung:Kaifa Learning. . (2016). Gurunya manusia. Bandung: Kaifa Learning

English, E. W. (2017). Pendidikan literasi. Bandung: Nuansa Cendekia

Murniati, E. (2012). Mengajarkan matematika dengan FUN. Yogyakarta: Mentari Pustaka.

Siddiq, D. (2008). Pengembangan bahan pembelajaran SD. Jakarta: Dirjen Pendidikan Tinggi Departemen Pendidikan Nasional.

Sudjana, N. (2013). Media pengajaran. Bandung: Sinar Baru Algesindo.

Sugiyono. (2010). Metode Penelitian Kuantitatif, Kualitatif \& RND. Bandung: Alfabeta 
Indonesian Digital Journal of Mathematics and Education Volume 6 Nomor 12019

http://p4tkmatematika.kemdikbud.go.id/journals/index.php/idealmathedu/ p-ISSN 2407-8530 | e-ISSN 2502-602X

How to Cite:

Hardani (2019). Penggunaan media PAJS untuk mengembangkan kecerdasan matematis dan interpersonal peserta didik dalam pembelajaran matematika materi skala. IDEAL MATHEDU:

Indonesian Digital Journal of Mathematics and Education, 6(1), 592-600. 